\title{
CITIZENSHIP AND IDENTITY IN DIVERSE SOCIETIES
}

\author{
MARK NOLAN AND KIM RUBENSTEIN
}

This article examines the relationship between the legal status of citizenship and psychological research about blended identity in diverse societies such as Australia. A blended identity could include Australian national identity as well as other identities relevant to a person's selfdefinition. Analysing the link between citizenship law and the psychological enjoyment of blended identity is important after the reforms to Australian citizenship law in 2007. ${ }^{1}$ As discussed below, the former Liberal-National Government introduced a new citizenship knowledge test for citizenship-by-conferral applicants. In doing so, that government expressed strong beliefs about the power of a shared, unitary, national identity. It also supported calls for citizenship applicants to sign a statement of Australian values (different to the citizenship pledge) and to complete an English language test. In light of the reforms and political debate, we attack the suggestion that blended identification (for example, as a Greek Australian) is somehow inconsistent with true Australian national identification and citizenship, and moreover we argue that a single national identification sits uneasily with the legal acceptance of dual or multiple citizenship in current Australian legislation.

We first discuss the concept of blended identity from a social-psychological perspective. Then we examine the details of the 2007 Australian citizenship law reforms, bearing in mind that the Rudd Labor Government recently released the report of the independent committee reviewing the Australian Citizenship Test and the government response to the report. $^{2}$

Legal notions of citizenship and the psychological experience of blended identities can often be in tension. This is understandable since legal and psychological concepts of national identity are but two ways of conceptualising relevant selfdefinitions shaping social existence and belonging in diverse societies. We do not believe that the legal identity or citizenship always completely defines the self in practice. However, we argue, as do other researchers, ${ }^{3}$ that citizenship law and psychological identity are in a relationship of mutual influence creating expectations about and reactions to legal treatment.

Notions of citizenship and associated assumptions about psychological identification that are legally endorsed in diverse societies have the power to legitimise as well as de-legitimise the desired enjoyment of self. Indeed, salient identities shape the perspective from which many people will either support or challenge citizenship law and decision-making processes. The extent to which the 2007 Australian reforms may have (de-)legitimised desired self-defini- 
tions will be examined in the final section of this article. Another way of addressing this issue is to consider whether citizenship law and application processing satisfy the basic human need for inclusion and for adequately expressing and enjoying all aspects of a blended identity. ${ }^{4}$

\section{PSYCHOLOGICAL-SOCIAL IDENTIFICATION}

This section begins by describing a process-based understanding of social identification. For example, an unsuccessful citizenship application results in particular self-definitions. So too could the existence of an official policy that treats different classes of citizens in different ways, such as testing only civics knowledge, values and language skills for particular citizen applicants and not, say, for Australians who are citizens by birth.

These situations can make a single identity salient and relevant for selfdefinition. However, sometimes such contexts can make a more complex blended social identity salient. For example, an instance of discrimination against Arab Australians could be relevant for their selfdefinition when reacting to felt discrimination. For example, this inter-group discrimination could result when an intelligence-gathering or policing decision is based on the assumption that one aspect of a person's identity (for example, their country of birth and/or religion) threatens national security by weakening their allegiance to Australia in some way. These assumptions and comparisons cause people to self-select identity or identities. However, context and comparisons can also cause people to be treated by others in terms of an identity even when they do not wish to so identify.

Both of these identity processes - selfdefinition and ascription of identity by others - narrow the number of identities used for self-definition. They render other aspects of self (for example, other identities based on, say, religion, gender, race, residence or political orientation) less relevant for shaping the immediate perspective from which people make social judgments, decisions or policies. This selection of relevant (or 'salient') identity by the social context has been demonstrated primarily by research focusing on changing operative social comparisons, but also by the nature of the normative content or ideologies related to salient identities. ${ }^{5}$

These contextual changes create identity management challenges for the social perceiver, helping them determine the psychologically best way to self-define or to respond to an (often unwanted) ascription of identity by another. Extending these process-based theories of singleidentity salience to the study of the simultaneous salience of many aspects or dimensions of self-definition ${ }^{6}$ constituting one blended identity is important for understanding citizenship and identity in diverse societies.

\section{BLENDED IDENTIFICATION AND ITS PSYCHOLOGICAL CONSEQUENCES}

\section{The concept of blended identity}

This article uses the term 'blended identity' to convey the concept that many different aspects or dimensions of self-definition can be salient simultaneously. In other words, it includes the situation where more than one identity simultan- 
eously shapes a person's self-definition in a particular social context. The study of blended identity is controversial, perhaps mainly due to the fact that some critics believe that this theoretical notion can be overstated. Some scholars reject talk of blended identity as naïve or unrealistic, concerned that some theorists suggest that the adoption of a blended identification is virtually automatic, common and universally desired. ${ }^{7}$ Of course, some migrants may wish to stop identifying in terms of an identity that, for example, represents a tyrannical regime from which they have escaped. Other critics of the notion of blended identity suggest that claiming that blended identification is common is simply another form of essentialism that suggests that migrants always identify in terms of these complex identities. This universalism is overstated in our view, and fails to explain the psychological processes determining when particular identifications occur. ${ }^{8}$ Our use of this concept, alongside empirical, process-based descriptions of blended identity salience, should reassure those critics.

The concept of blended identity has been discussed by researchers from a number of different disciplines. Other common terms include: dual nationality, dual citizenship, ethnic national identity, 9 hyphenated identity or ethnicity, ${ }^{10}$ or simply mixed identities. In particular, social psychologists have sometimes labelled blended identities as 'crossed categorisations' to describe the combination or 'crossing' of many identities to form a complex identity. There have been three decades of social psychological research into phenomena flowing from blended identifications. This has mainly involved research into how crossed categorisations shape perceptions of other group members. For example, being biased in favour of your in-group (that is, the identity perspective made salient for you by a social comparison) and distinguishing self from and/or thinking negatively of out-groups (that is, groups and their perspectives with which you do not feel a sense of belonging in the context of a particular social controversy). ${ }^{11}$

The term 'crossed categorisation' reflects theoretical ideas about social identity salience described above. In the case of blended identity salience, the social context makes salient at least two identities, rather than simply one identity. This more complex categorisation or definition of the self is the perspective from which people determine their identity-based beliefs and ideologies. 12 Importantly, researchers study crossed categorisations that include the salience of national identities as part of a blended identification. ${ }^{13}$

If people have many constituent aspects of self, it should not be surprising that sometimes two or more of these identities are simultaneously salient and responsible for shaping our perspective on a social issue. Perhaps these more complex, blended identities are in fact more normal for some people including migrants than is the simpler case of the salience of only one (national) identity. The burgeoning interest in the social psychology of crossed categorisations is a valuable addition to citizenship research. It is useful to consult research on crossed categorisation before citizenship law reform championing identification with only one single national identity is thought superior to celebrating blended identity. 


\section{Measurement of identification with a blended identity}

Verkuyten studied the relative strength of religious and national identification in a sample of 206 Turkish-Dutch citizens who identified as Sunni Muslims. Attitudes, though not real behaviours, towards other religious groups in the Netherlands were also measured. The study was conducted in the context of what Verkuyten describes as Dutch citizenship policies promoting assimilation via strong national identification. ${ }^{14}$

Verkuyten found that half of the sample rated their Islamic identity as strongly as they could on all measurement dimensions, choosing seven on a sevenpoint rating scale on all measures of the importance of the Islamic identity. This ceiling effect or 'total' identification as a Muslim within these blended identities was interpreted as supporting studies showing the very high importance of Islamic identity for Muslims living blended identities in the West. ${ }^{15}$

For these 'total' Muslim identifiers, the religious component of identity appeared a highly central way of defining self in the social judgment contexts examined. Importantly, even though half of the participants had a 'Muslim identity [that] was an integral or inextricable part of how they saw themselves', 16 their Dutch national identification was not eliminated. Their Dutch national identification was significantly lower than the national identification of the other half of participants whose Islamic identity was strong though not 'total'. Those with 'total' identification rated their in-group most positively and felt strongly about Islamic group rights. However, Verkuyten could still classify 19 per cent of the 'total' Muslim identifiers as high Dutch identifiers (who rated the importance of that identity above the midpoint of the response scale). Also, 31 per cent of high Muslim identifiers simultaneously identified as Dutch nationals and had high levels of national identification.

For some, the impact of strong religious identification upon national identification could appear alarming. However, the observable psychological benefits of these blended identities are an important part of evaluating any alleged risk of blended identification. For these 'totally identified' Muslim participants, the most negative feelings towards other religious groups in the Netherlands were towards non-believers. When total Muslim identification and high national identification co-occurred, hostility towards other religious groups (Jews, Christians, Hindus) decreased. Most negative beliefs about other Dutch religious groups were held by total Muslim identifiers with low national identification, suggesting that hostile beliefs were caused more by a single rather than a blended identification.

These data suggest the importance of relationships between each aspect of a blended identity for resulting social attitudes (that is, beliefs about nationality and about religious groups to which the perceiver does or does not belong). It does not suggest, however, that high or total identification as a Muslim always eliminates or suppresses national identification. This detail of this study is highlighted as an example of the type of research that should be conducted and consulted in order to understand the subtle dynamism of blended identity expression in political contexts. The reasons why a blended identifier does or does not strongly 
identify as a national of their country of residence is an important social-psychological and political question. Not only do these data suggest the reality of blended identities and the possibility of identification with a blended identity and high national identification, these data suggest that detailed measurement of the impact of citizenship regimes is needed so we can better understand exactly how and when citizenship regimes may stifle blended identities or allow them to exist.

Verkuyten notes too that crossing religious identity with national identity is an example of a complex blended identity, perhaps even more complex than combining two national identities or, say, language groups. ${ }^{17}$ It should be remembered that each example of crossed categorisation, in political and historical context, will produce its own unique identity management challenges. Possible social tensions that result are not simply a function of whether blended rather than single identity salience occurs but are influenced by relationships between the constituent identities in a crossed categorisation and social treatment of these identities.

\section{Common in-group identity research}

Some social psychologists argue that adopting one superordinate, common in-group identity (for example, Australian) within diverse societies can reduce tension and hostile beliefs between groups. However, some researchers have found this occurs when valued cultural identities (for example, Arab identity) can remain strong following identification with the common in-group identity (for example, Australian). 18 This suggests the benefit of blended identification that prevents mere recategorisation of all subordinate identities into a higher-order national identity. Rather than replacing this diversity with a unitary national identity, there is benefit in promoting a superordinate Australian citizenship that allows explicit and continuing identification with other elements of a blended identity.

Similarly, important recent empirical work reveals the impact on in-group bias when making a common in-group identity salient whilst measuring how people perceive the relative importance of maintaining a crossed categorisation. ${ }^{19}$ In this work, the perceived importance of the crossed categorisations determined whether use of a common in-group identity (for example, Australian) resulted in harmony and perceived inclusiveness instead of continuing tension and continuing perceptions of inter-group difference. Results showed that when the elements of a blended identity remained subjectively important for a perceiver, then identifying only in terms of a common in-group identity did not reduce perceived inter-group tension between subordinate identities.

\section{SOCIAL RESEARCH ON BLENDED NATIONAL IDENTITY}

In this section, social research on blended identity provides further examples of blended identification. Two examples are drawn upon: British Muslims and citizenship, as well as studies of Latin Australians.

\section{British Muslims and citizenship}

In line with other theorists, ${ }^{20}$ social psychologists Hopkins et al. suggest that sensitivity to cultural diversity has also created a tension between the actuality of a plurality of social identities and the 
singular identity implied by citizenship'. 21 In terms of self-categorisation theory, 22 these researchers analysed how British Muslims used Islamic identity to encourage or dissuade citizens voting during the 1997 general election. The British National Party (BNP) claimed that there was a contradiction between being a Muslim and being a British citizen. Against this political backdrop, the Muslim Parliament of Great Britain asked British Muslims to boycott the polls and to demand alternative institutional arrangements through which they could express their political views. ${ }^{23}$ They also claimed a degree of identity incompatibility, stating that British Muslims could not be loyal to the Labour Party and God at the same time. ${ }^{24}$ The Muslim Parliament called for British Muslims to live up to the example of the Prophet and to aim for interaction with the community without integration in Britain.

To counter that call, the UK Action Committee on Islamic Affairs cited Qur'anic verse to produce an anti-boycott message encouraging British Muslims to vote in order to fulfil the duty they owed to Britain. This civic duty as British citizens was asserted to be the same type of outward-looking, communal duty they owed as Muslims to other Muslims.

This political debate is a dramatic example of how blended identity can be used for political purposes in a dispute over citizenship rights (voting and representative democracy). It demonstrates that blended identity allows for the possibility of encouraging, as well as sometimes dissuading, civic participation when using rhetoric derived from all the aspects of a blended identity. Hopkins et al. state there is little use concluding that blended iden- tities will always have negative effects for national politics and harmony. The researchers note that conceptualising subjective notions of citizenship or blended British Muslim identity as fixed, essentialistic, homogenous or universally expressed concepts is misguided. Even if the BNP believed there was only one essential type of British Muslim, analysis of the real political context showed that there could be at least two British Muslim views on the importance of voting in the general election, both derived from Islamic texts. The ideological content of blended identifications and descriptions of citizenship will vary in line with specific political context and the political end sought, as may the case when single category national identities are used for political purposes. ${ }^{25}$

This dynamism should not be perceived as a weakness of blended identification per se. It is not as if all blended identities have an essence tending towards inevitable identity conflict. Rather, the social constructions revealed in this study reflected strategic political behaviour from a salient identity perspective. It demonstrates that each element of blended identification can be mutually reinforcing, as much as they can be antagonistic. In this sense, the research shows that one group of highly identified British Muslims sought political autonomy that downplayed the significance of British citizenship rights. The other, a similarly highly identified group of British Muslims, argued for election voting and full civic participation as a core duty consistent with their Muslim identity. The latter political approach demonstrated an ability to unify both aspects of their crossed categorisation despite political attack suggesting that a single British citizenship must prevail as 
it was inconsistent with blended identification as a British Muslim.

\section{Identification by Latin Australians}

Zevallos conducted a study of 13 young (seventeen to twenty-five year old) women of Latin American heritage living in Australia. ${ }^{26}$ Five of the participants were Australian born, and the remaining eight had come to Australia between the ages of two and seven. One finding obtained was that 11 of the 13 interviewees rejected the notion that their identities were best captured by the simple label 'Australian'; only two interviewees were happy with that label, having grown up in Australia.

This rejection of the singular label Australian did not mean they rarely felt Australian, or had low attachment to Australia. Indeed, they felt most Australian, and were treated most as Australians, when travelling in Latin American countries. ${ }^{27}$ When this salience occurred, they readily attributed traits, views and behaviours to their 'Australian side' or to the Australian influence upon their selfdefinition as, say, 'a South American living in Australia'. When discussing gender and sexuality issues, for example, the women endorsed values of egalitarianism as an Australian influence. In terms of the citizenship values debate in Australia, it is noteworthy that use of a blended identity does not mean these interviewees failed to endorse values (for example, egalitarianism) that some would claim as Australian.

Most of the women reported that Australia was considered to be home and where they hoped to have careers and children; interviewees contemplated only holidays in Latin American countries. However, they still preferred not to be defined simply as Australian. Based on the data collected, Zevallos concluded that: 'There has been no consensus on the best way to bridge the gap between the ideology of multiculturalism and an all-encompassing Australian identity.' 28

Perhaps the missing consensus on the best way to bridge the gap between the ideology of multiculturalism and an allencompassing Australian identity is to truly celebrate the existence of blended identities socially, politically and legally. Indeed, Australian citizenship law has moved from a rejection of dual or multiple citizenships to an acceptance and affirmation of these in legislation, to which this article now turns.

\section{AUSTRALIAN CITIZENSHIP LAW}

\section{Dual or multiple citizenship in Aus- tralia}

From the inception of the Australian Citizenship Act 1948 (Commonwealth) until 4 April 2002, there was a provision mandating loss of Australian citizenship for a person who acquired a new citizenship. This was found in Section 17 of the act ('Loss of citizenship on acquisition of another nationality'). ${ }^{29}$

Section 17 and the deterrence of dual citizenship was one of the most contested and contentious areas of the Australian Citizenship Act 1948 (Cth). Dual citizenship was the subject of a 1976 review by the Joint Committee on Foreign Affairs and Defence and it was also considered in the context of the national consultations on multiculturalism and citizenship conducted in 1982. Then, two further reviews considered the worthiness of s. 17, 30 and a related parliamentary review of s. 44(i), which disqualified dual citizens from be- 
coming Members of Parliament, also considered related policy matters. ${ }^{31}$

At one level there was a basic inequality in the system. When citizens of another country became Australian citizens, the approach in practice had varied. The pledge taken upon becoming an Australian citizen has changed over the years. Between 1966 and 1986 the words included 'renouncing all other allegiance'. ${ }^{32}$

However, this wording had no legal consequence for their status as citizens of the other country. As a matter of international law, it is a question for the country which bestows citizenship to determine whether someone loses that citizenship - it is an incident of sovereignty of that nation-state. The leading case on the question of nationality for the purpose of diplomatic protection is the 1955 Nottebohm case. $^{33}$

The High Court of Australia confirmed this in Sykes v. Cleary, 34 in which two of the people running for Parliament, and whose positions were challenged, were citizens of other countries, Greece and Switzerland, and therefore ineligible under s. 44(i) of the Australian Constitution.

The issue of dual citizenship became quite central to the deliberations of the Australian Citizenship Council. In August 1998, the Howard Government established the council as an independent body to advise it on Australian citizenship matters. In a report at the end of 1999, later published as Australian Citizenship for a New Century, the council made 64 recommendations including the repeal of Section 17. Considering matters such as globalisation, the Australian Citizenship Council stated:

[A]s we move into the twenty-first century, the prevalence of dual citizenship internationally will rapidly increase. The law and practice of most countries with which Australia likes to compare itself permits citizens of those countries to obtain another citizenship without losing their original citizenship...These countries simply recognize that they have an internationally mobile population and that they can retain connection with this population even if another citizenship is acquired. $^{35}$

This recommendation was acted upon by the government and implemented in the 2002 amendments to the act, which were then enhanced by the 2007 reforms to which discussion now turns.

\section{Howard Government policy reforms in 2007}

In 2007, the Howard Government introduced two separate pieces of legislation on citizenship that had different policy objectives. The first was the repeal of the 1948 statute with a new Australian Citizenship Act 2007. The second (and after the first was fully implemented) was an amendment to the new act introducing more elaborate citizenship testing.

\section{The 2007 act}

The Australian Citizenship Act 2007 came into force on 1 July 2007. As the Reader's Guide to the new act outlines, 36 the origins of the 2007 act lie with the former Australian Citizenship Council (the council). In its report at the end of 1999, referred to above, within its 64 recommendations was 'Refining the structure of the Australian Citizenship Act 1948'. 37 The 2007 act's origins lie with that recommendation. 
While all the other substantive changes to the 1948 act recommended in the council's report (such as the repeal of Section 17 of the former act to allow for dual citizenship) were implemented in legislation in 2002, this last recommendation to 'tidy up' the act 'to improve presentation so it is logically organized, numbered and consistent, with relevant matters dealt with together, and ensuring the balance of matters dealt with between the Act and the Regulations conforms to modern standards' was implemented with the passage of the Australian Citizenship Act 2007 (the new act).

The act has a more logical structure, including terminology that is more accessible and changes complementing the policy rationale of the 2002 amendments, as well as some further changes to assist Australia in better responding to the threat of terrorism. 38

The most significant change from the perspective of this article emanating from the report was the 2002 repeal of s. 17 of the original citizenship act. The new 2007 act extended that inclusive approach to Australian citizenship in various ways, including broadening the resumption of citizenship provisions and the extension of citizenship by descent to children of people who had lost their Australian citizenship.

These latter changes were part of the package that could be referred to as inclusive; they were including in the Australian community many people who had often seen themselves as Australians, but had not been recognised formally in law as such, and importantly for our discussion of blended identity, included dual citizens in the fullest legal sense. However, very soon after the passage of the new legisla- tion, an amendment act, which was introduced before the core legislation, was passed, ${ }^{39}$ underpinned by a less inclusive policy approach to Australian citizenship, as set out below.

\section{Citizenship testing}

Before the 2007 citizenship test reforms, citizen-by-conferral applicants generally had their language ability assessed at interview, though there was no standardised or objective test of English language proficiency. ${ }^{40}$ There was no formal written citizenship knowledge test administered, save for applicants needing to demonstrate at interview a satisfactory understanding of the rights and responsibilities of Australian citizenship. Citizenship applicants then needed to make the Citizenship Pledge (see below).

Following the passage of the Australian Citizenship Amendment (Citizenship Testing) Bill 2007, the minister can require certain applicants to sit a formal citizenship test (which may include English language testing as well as civics knowledge testing). ${ }^{41}$ A review of the amendment act is thoroughly canvassed in the Parliamentary Bills Digest. ${ }^{42}$ As part of the new administrative system, a resource book is available for prospective applicants to read, ${ }^{43}$ and from which information is available that will assist applicants in answering the randomly selected questions drawn from a secret set.

The department publishes Citizenship Test Snapshot Reports on a regular basis. ${ }^{44}$ The latest information about the testing reveals some form of substantive discrimination against test applicants from the humanitarian migration stream. The reporting from the Department of Immigration and Citizenship indicates that between 1 
October 2007 and 30 June 2008, 48713 individuals sat the citizenship test and 46 500 (or 95.5 per cent) passed it on their first or subsequent attempt. ${ }^{45}$ The pass rate (on first or subsequent attempt) for applicants who came to Australia under the Skilled Stream of the Migration Program was 99 per cent compared with 92 per cent for those who came under the Family Stream and 82 per cent for those applicants who came under the Humanitarian Program. Also, the average number of tests needed to be taken before passing per applicant appears greater for humanitarian (1.8) compared with family (1.3) and skilled migrant (1.1) applicants. The number of test applicants from each migration stream is as follows: skilled (48 per cent), family (22.2 per cent) and humanitarian (11.3 per cent).

\section{THE IMPACT OF AUSTRALIAN CITIZENSHIP LAW REFORM ON BLENDED NATIONAL IDENTITY}

Below, two possible results of inappropriate treatment of blended identities are considered: 1) increased identification following threat to one (national) identity; and 2) variations in identity attachment. The concept of honourable citizenship ${ }^{46}$ is also discussed below as a guide to how some migrants may wish their blended identity to be respected: needing their country of origin to be acknowledged and respected, rather than demonised or treated as if it is no longer psychologically significant. This section of the article considers whether the Howard Government's citizenship reforms and policies widen rather than bridge the gap between citizenship law and healthy psychological enjoy- ment of blended identity in diverse societies.

A single Australian identity: is keeping it simple stupid?

In the citizenship testing discussion paper, the Howard Government defined the desired normative content of an Australian identity:

Citizenship provides an opportunity for people to maximise their participation in society and to make a commitment to Australia's common values - which include the respect for the freedom and dignity of the individual, our support for democracy, our commitment to the rule of law, our commitment to the equality of men and women and the spirit of a fair go, or mutual respect and compassion to those in need. ${ }^{47}$

These values are similar though much more detailed and, perhaps, ideologically driven than the current citizenship pledge, which reads: 'From this time forward [under God], ${ }^{48}$ I pledge my loyalty to Australia and its people, whose democratic beliefs I share, whose rights and liberties I respect, and whose laws I will uphold and obey. 49

Zevallos cites Kukathas' warning that conflict is likely when culturally pluralistic societies such as Australia attempt to endorse a strong sense of national identity via reshaping of Australian institutions (including citizenship law) with the aim of further defining what it means to be an Australian. ${ }^{50}$ In light of these warnings, the most troubling aspect of the Howard Government's rhetoric surrounding its 2007 citizenship reforms was the official endorsement of citizenship as the celebra- 
tion of a simple, single national identity and as the best solution to inter-group tension or personal maladjustment. As attractive and consensual as this focus may at first appear, it asserts equivalence between a single citizenship identity and real psychological identification that may not exist in all cases. The government's preferred approach in 2007 was to encourage use of a single 'superordinate identity' to all new Australian citizens irrespective of their migration history and the extent to which a blended identity was important to them.

Instead of suggesting that true celebration of blended identity could create stability in a diverse society, the Howard Government's Discussion Paper on citizenship testing suggested that sustainable unity came via a simple, single national identity: 'Australian Citizenship is the single most unifying force in our culturally diverse nation. It lies at the heart of our national identity - giving us a strong sense of who we are and our place in the world. ${ }^{51}$

Unlike our thesis - that true recognition of blended identity may sometimes reduce social tension - the official endorsement of citizenship in 2007 was linked simply to identification as Australian; suggesting that diversity and harmony was strengthened rather than weakened by emphasising one Australian national identity in all contexts and in response to all social comparisons within Australia. Testing English language proficiency, Australian civics knowledge and asking applicants for an endorsement of Australian values were tools thought by the Howard Government to facilitate adoption of this simple (non-blended) identity. No other route to harmonious multicultural relations was considered to be as effective. For example, there was minimal if any emphasis upon unity in diversity and little suggestion that the celebration of blended identity could assist relations in some, even if not all, possible social contexts.

\section{Identity threat}

The Howard Government's one-citizenship-satisfies-all approach to unity in diversity may result in threats to some of the identities comprising a blended identity. Much social-psychological research confirms that one reaction to identity threat is increased rather than decreased identification with the threatened identity, especially for those who strongly identify with the threatened identity. ${ }^{52}$ For those who highly identify with a threatened identity, and who wish to continue to selfdefine in those terms, rejection of a single Australian identity that threatens other components of their blended identity seems likely. This prediction, supported by results of designed laboratory research, has also been demonstrated in recent field studies. For example, in response to assimilationist citizenship policies in the Netherlands, Islamic groups whose religious identity was threatened strongly identified with that identity in response to public condemnation of continuing identification as a Dutch Muslim. ${ }^{53}$ Such results would be at odds with the Howard Government's claim that using (simple) notions of Australian citizenship and identity was the single most unifying force in our diverse society, producing 'a strong sense of who we are' 54

\section{Attachment to Australia}

Attachment to Australia was important for the Howard Government in 2007, stating that: 
Becoming an Australian is much more than a ceremony. It is an opportunity to fully embrace the Australian way of life, to broaden education options and employment opportunities, to vote and to have a voice in the country's future...People taking up Australian citizenship are welcomed into one of the safest, most tolerant and peaceful societies in the world. ${ }^{55}$

Davis, in his review of social-psychological theories of national attachment and his empirical study of Basque attachment in Spain, suggests that measuring subjective attachment to nation is much more complex than measuring values endorsement. Davis's review suggests that values-based attachment is important, though it can be of less importance than measures of emotional ties to nation or of institutional responsibilities. ${ }^{56}$ Even Davis's analysis of Basque attachment revealed two distinct perspectives: 'guardian nationalism' and 'apolitical ethnicity'. Only the former of those attachment styles was defined centrally around values such as language maintenance, self-determination and armed separatism. Davis also emphasised that careful empirical work was required to understand subjective attachment to nation for those self-defining in terms of blended identities; rejecting the utility of understanding attachment to nation in terms of commonly asserted and universal dimensions of attachment. ${ }^{57}$ Arab Australian Waheed Aly suggests that the Howard Government's policy of compulsory language testing and knowledge testing was mooted for political reasons and cannot provide an effective way to increase the attachment to Australia or the participation in civic life:
The tests would ask pointless questions about Don Bradman ${ }^{58}$ and Phar Lap, ${ }^{59}$ not because this assisted migrants with integration in any practical way, but because it was intended to send a symbolic message to a specific constituency in the electorate. A sector that seeks reassurance that the only migrants who will make it through are the good ones. ${ }^{60}$

Aly believes that the testing regime could emphasise a 'suffocating...p parochial cultural paradigm' ${ }^{61}$ neither giving practical help to migrants living in Australia nor improving social relations and attachment to Australia.

\section{Honourable citizenship}

Ghassan Hage fears that Australians with blended national identities in diverse societies such as Australia, who even have achieved their clear entitlements to citizenship rights, can still feel 'demeaned as a human being' 62 when accessing rights offered to them. Hage argues that most Arab migrants to Australia are 'reasonably likely to end up accessing Australian citizenship and/or the rights that come with it or with residency status' ${ }^{63}$ Therefore, he argues, the real social problems (social exclusion or isolation, inequality and discrimination) revolve around the ways in which you must access these rights and how you feel when doing so.

Hage stresses that citizenship is primarily about a (psychological) sense of belonging and about 'holding your head high' as, say, an Arab Australian. Being able to do so is, in Hage's terms, to be able to enjoy honourable citizenship. Such a form of citizenship in practice is determined by whether the legal conceptions of 
citizenship or, 'rule over the self', 64 deliver a sense of dignity, autonomy and honour. He claims that this goes beyond the common situation in diverse multicultural societies where refugees or migrants are offered a chance to belong to Australian society because they cannot or no longer wish to live in and identify with their country of origin. According to Hage, then, honourable citizenship for dual nationals means that the mode of accessing rights and the official displays of inclusion and recognition should emphasise and celebrate the continued moral worth of all elements of a blended self-identity.

Hage argues that explicit and transparent efforts be made to consider the impact on blended identities when the Australian Government makes foreign policy or other official decisions. This, in effect, would involve considering how actions taken in the Australian interest may affect those with salient blended identities. ${ }^{65}$ Honourable citizenship also means that the history and origin of, for example, an Arab identity is honoured by being given clear support as a legitimate identity with past, present and future moral worth. Making simpler calls for integration or assimilation via citizenship and identification as (only) an Australian, who speaks good English, has good civics knowledge and who endorses Australian values, may sometimes be at odds with the notion of honourable citizenship. $^{66}$

Hage concludes by encouraging Arab Australians to treat Australia as a home and to participate in Australian society despite their real fears of being discriminated against and of not being able to live their blended identities in ways they would hope. ${ }^{67}$ In saying so, he hopes Arab Australians will be encouraged not to forget their other homes. He also notes that the movement of people to Australia is dynamic, continuing and less final than it may have once been, with many migrant families now going back and forth rather than making one-movement migrations to Australia. ${ }^{68}$ In contemplating the future of the citizenship test, the Rudd Government should recognise that many Australians juggle two or more national identities. For blended identification to be matched by sensitive laws on dual or multiple citizenship, 'petty fears of double allegiance $^{\prime 69}$ must give way in law and practice to a diverse society in which blended identification can truly flourish for the benefit of all.

\section{CONCLUSION}

If one goal of Australian citizenship law is to legally recognise the reality of blended identities, governments need to create citizenship law that allows for self-definition via crossed categorisations. Outward displays of attachment to and enjoyment of all aspects of a blended identity should not engender undue moral panic. Instead, citizenship should be considered to operate richly and dynamically in ways similar to other examples of crossed categorisations unless evidence exists of unique psychological process and universally negative social psychological consequences for citizenships lived as crossed categorisations.

This article has explained that some concerns about blended identifiers - that they will be more biased or are less attached to Australia - are not sustained by research evidence. These concerns are longstanding assumptions that have been under-researched, even by identity psy- 
chologists. $^{70}$ The way in which citizenship law and policy creates tension between elements of blended identities is important:

These identities do not have to
contradict each other or get in
each other's way because they are
of different kinds: they are differ-
ently defined or situated on differ-
ent levels of abstraction. One can
be a member of an ethnic group as
well as a superordinate national
category. There is little problem
as long as these identities are not
defined on the same level of ab-
straction and in contrasting or
competing terms. Depending on
the situation the one or the other
is relevant and becomes salient.
However, different identities do
sometimes get in each other's
way.

Blended identity salience is a dynamic and context-dependent process, and is not a fanciful, postmodern, theoretical concept. It is the lived reality for many citizens. The celebration of blended identity rather than the ascription of an ill-fitting singular Australian identity may be a better way to encourage psychological attachment to the many ways in which Australian citizenship can be enjoyed.

\section{POSTSCRIPT}

The Rudd Government released the report of the Australian Citizenship Test Review Committee, Moving Forward...Improving Pathways to Citizenship, and the government response to that report after this article was written (see <http://www.citizenshiptestreview.gov.au/index.htm>).
Kim Rubenstein was a member of the committee. When the government releases the new citizenship test and the pathways to taking the test as a result of its response to the report, we will then be able to consider how well the changes deal with the issues raised in this paper.

\section{ENDNOTES}

1 See reforms as discussed below. Note also that on 24 January 2007, the Department of Immigration and Multicultural Affairs was renamed the Department of Immigration and Citizenship.

2 The Minister for Immigration and Citizenship established an independent committee to review the Citizenship Test in April 2008 (see < http://www.citizenshiptestreview.gov.au/ >).

3 Dauvergne, C. 2005, Humanitarianism, Identity and Nation: Migration laws in Canada and Australia, UBC Press, Vancouver, pp. 166-221; Mamdani, M. 2001, When Victims Become Killers: Colonialism, nativism, and the genocide in Rwanda, Princeton University Press, Princeton, NJ, p. 22; Purvis, T. and Hunt, A. 1999, 'Identity versus citizenship: transformations in the discourse and practice', Social and Legal Studies, vol. 8, no. 4, pp. 457-82; Reicher, S. 1986, 'Contact, action and radicalisation: some British evidence', in M. Hewstone and R. Brown (eds), Contact and Conflict in Intergroup Encounters, Basil Blackwell, Oxford, pp. 152-68; Ramos, E. Rivera 2001, The Legal Construction of Identity: The judicial and social legacy of American colonialism in Puerto Rico, American Psychological Association, Washington, DC.

4 Abu-Saad, I. 2006, 'State-controlled education and identity formation among the Palestinian Arab minority in Israel', American Behavioral Scientist, vol. 49, no. 8, pp. 1085-100.

5 Oakes, P. J. 1987, 'The salience of social categories', in J. C. Turner, M. A. Hogg, P. J. Oakes, S. Reicher and M. Wetherell (eds), Rediscovering the Social Group, Blackwell, Oxford; Oakes, P. J., Turner, J. C. and Haslam, S. A. 1991, 'Perceiving people as group members: the role of fit in the salience of social categorizations', British Journal of Social Psychology, vol. 30, no. 2, pp. 125-44.

${ }^{6}$ Where a broad range of personal aspects, including affiliations with groups, may help define a collective or blended identity: Simon, B. and Hastedt, C. 1999, 'Self-aspects as social categories: the role of personal importance and valence', European Journal of Social Psychology, vol. 29, no. 4, pp. 479-87. See also Simon, 


\section{Citizenship and identity in diverse societies}

B. 1997, 'Self and group in modern society: ten theses on the individual self and the collective self', in R. Spears, P. J. Oakes, N. Ellemers and S. A. Haslam (eds), The Social Psychology of Stereotyping and Group Life, Blackwell, Oxford, pp. 318-35.

7 Cashmore, E. 2003, 'The impure strikes back', British Journal of Sociology, vol. 54, no. 3, pp. 407-14, 411, citing Kumar, K. 2003, The Making of English National Identity, Cambridge University Press, Cambridge, p. 258.

8 Ibid., p. 411, citing Anthias, F. 2001, 'New blendedities, old concepts: the limits of "culture", Ethnic and Racial Studies, vol. 24, no. 4, pp. 619-41, 637.

9 Korac, M. 1996, 'Understanding ethnic-national identity and its meaning: questions from women's experience', Women's Studies International Forum, vol. 19, no. 1-2, pp. 133-43; Verkuyten, M. 2005, The Social Psychology of Ethnic Identity, Psychology Press, London.

10 Duany, J. 2003, 'Nation, migration, identity: the case of Puerto Ricans', Latino Studies, vol. 1, no. 3, pp. 424-44; Glazer, N. 2004, 'Assimilation today: is one identity enough?', in T. Jacoby (ed.), Reinventing the Melting Pot: The new immigrants and what it means to be American, Basic Books, New York, pp. 61-73; Mahtani, M. 2002, 'Interrogating the hyphennation: Canadian multicultural policy and "mixedrace" identities', Social Identities, vol. 8, no. 1, pp. 67-90.

11 Mullen, M., Migdal, M. J. and Hewstone, M. 2001, 'Crossed categorization versus simple categorization and intergroup evaluations: a meta-analysis', European Journal of Social Psychology, vol. 31, no. 6, pp. 721-36.

12 For an early example of experimental research with crossed categorisations, see Brown, R. J. and Turner, J. C. 1979, 'The criss-cross categorization effect in intergroup discrimination', British Journal of Social \& Clinical Psychology, vol. 18, no. 4, pp. 371-83.

13 Verkuyten, M. 2007, 'Religious group identification and inter-religious relations: a study among Turkish-Dutch Muslims', Group Processes and Intergroup Relations, vol. 10, no. 3, pp. 341-57.

14 Ibid.

15 Ibid., p. 343: supporting observations from H. C. Triandis (1992, 'Comments on Hinkle, Brown and Ely', Revisita de Psicologia Social, vol. 3, pp. 113-23) that for some identifications in some cultures, one is clearly a (strongly identified) member of a group or one is not. This could mean that group identification is a binary choice rather than a form of belonging that can be measured on a continuum in terms of low and high identification. Being a low identifier with these identities is not an option.
16 Ibid., p. 347.

17 Ibid., p. 351.

18 Hornsey, M. and Hogg, M. 2000, 'Subgroup relations: a comparison of mutual intergroup differentiation and common ingroup identity models of prejudice reduction', Personality and Social Psychology Bulletin, vol. 26, pp. 242-56.

19 Crisp, R. J., Walsh, J. and Hewstone, M. 2006, 'Crossed categorization in common ingroup identity contexts', Personality and Social Psychology Bulletin, vol. 32, no. 9, pp. 1204-18.

20 Purvis and Hunt, 'Identity versus citizenship', p. 458.

21 Hopkins, N., Reicher, S. and Kahani-Hopkins, V. 2003, 'Citizenship, participation and identity constructions: political mobilization amongst British Muslims', Psychologica Belgica, vol. 43, no. 1-2, pp. 33-54, 34.

22 Turner et al., Rediscovering the Social Group.

23 Hopkins et al., 'Citizenship, participation and identity constructions', pp. 42, 39.

24 Ibid., p. 42.

25 Ibid., p. 34.

26 Zevallos, Z. 2003, “That's my Australian side". The ethnicity, gender and sexuality of young Australian women of South and Central American origin', Journal of Sociology, vol. 39, no. 1, pp. 81-98.

27 Ibid., pp. 88-9.

28 Ibid., p. 85 .

29 For a more detailed examination of dual citizenship in Australia, see Rubenstein, K. 2002, Australian Citizenship Law in Context, Law Book Company, Sydney.

30 See Parliament of the Commonwealth of Australia (1994, Australians All: Enhancing Australian citizenship, Joint Standing Committee on Migration, ch. 6), where it is stated that the issue of dual citizenship attracted most attention throughout the inquiry.

31 Parliament of Australia 1997, Aspects of Section 44 of the Australian Constitution, Standing Committee on Legal and Constitutional Affairs, July 1997.

32 Introduced by Act No. 11 of 1966, s. 11 (commenced 6 May 1966) and repealed by Act No. 70 of 1986, s. 11 (commenced 28 August 1986).

33 Judgment of 6 April 1955: ICJ Reports 1955, p. 4.

34 (No. 2) (1992) 176 CLR 77.

35 Australian Citizenship Council 2000, Australian Citizenship for a New Century, p. 65, < http://www.citizenship.gov.au/law-and-policy/legislation/report.htm> 
36 The Readers' Guide is available at < http://www.citizenship.gov.au>

37 Ibid., pp. 78-81.

$38 \quad$ See <http://www.pm.gov.au/media/release/2005/media_Release 1551.cfm $>$. In particular, they include extending the waiting period for obtaining citizenship, security checking of citizenship applications, so that citizenship applications can be refused on security grounds, and strengthening the deprivation of citizenship provisions relating to serious criminal offences to include offences committed in the period between approval of an application and acquisition of citizenship.

39 It was introduced into the House of Representatives on 30 May 2007 (see <http://parlinfoweb.aph.gov.au/piweb/Repository/Legis/Billsdgs/YREN60.pdf $>$, viewed 24 February 2008), and the act that it was seeking to amend came into force on 1 July 2007.

40 Australian Government 2006, Australian Citizenship: Much more than a ceremony, September 2006, pp. 8-9.

41 As a result of amendments reflected in the Australian Citizenship Act 2007 (Cth), ss 21(2)(d)-(f), 21(2A), 23A, 46(1A) and 53(2).

42 Rimmer, S. Harris 2007, 'Australian Citizenship Amendment (Citizenship Testing) Bill 2007', Bills Digest, Parliamentary Library of Australia, no. 188, 19 June 2007, viewed 24 February 2008, <http://parlinfoweb.aph.gov.au/piweb/Repository/Legis/Billsdgs/YREN60.pdf>

43 See information about the test and a link to the booklet at <http://www.citizenship.gov.au/test/resource-booklet/citz-booklet-full-ver.pdf $>$ (viewed 24 February 2008).

44 See <http://www.citizenship.gov.au/resources/facts-and-stats/citz-stats.htm $>$ (viewed 24 February 2004).

45 See <http://www.citizenship.gov.au/resources/facts-and-stats/citz-stats.htm $>$ (viewed 22 September 2004) and the latest report available at <http://www.citizenship.gov.au/_pdf/citztestsnapshot-report-2008-june.pdf $>$ (viewed 22 September 2008).

46 Hage, G. 2002, 'Citizenship and honourability: belonging to Australia today', in G. Hage (ed.), Arab Australians Today: Citizenship and belonging, Melbourne University Press, Melbourne, p. 3.

47 Australian Government, Australian Citizenship, p. 8.

48 The words 'under God' are optional.

49 Australian Citizenship Act 2007 (Cth), Schedule
50 Zevallos, “"That's my Australian side"”, p. 86.

51 Australian Government, Australian Citizenship.

52 Spears, R., Doosje, B. and Ellemers, N. 1997, 'Selfstereotyping in the face of threats to group status and distinctiveness: the role of group identification', Personality and Social Psychology Bulletin, vol. 23, pp. 538-53; Branscombe, N. R., Ellemers, N., Spears, R. and Doosje, B. 1999, 'The context and content of social identity threat', in N. Ellemers, R. Spears and B. Doosje (eds), Social Identity: Context, commitment, content, Blackwell Science, Oxford, England, pp. 35-58.

53 Verkuyten, M. and Zaremba, K. 2005, 'Inter-ethnic relations in a changing political context', Social Psychology Quarterly, vol. 68, pp. 375-86.

54 Australian Government, Australian Citizenship.

55 Ibid., p. 11.

56 Davis, T. C. 1999, 'Revisiting group attachment: ethnic and national identity', Political Psychology, vol. 20, no. 1, pp. 25-47.

57 Ibid., pp. 32-3.

58 An Australian cricketer.

59 An Australian racehorse and winner of the Melbourne Cup.

60 Aly, W., 'End of the culture wars', viewed 14 January 2008, <http://www.australiansall.com.au/the-end-of-the-culture-wars/>

61 Ibid.

62 Ibid.

63 Hage, 'Citizenship and honourability', p. 2.

64 Ibid., p. 3.

65 Ibid., p. 10.

66 Ibid., p. 11.

67 Ibid., pp. 14-15.

68 Ibid., p. 12.

69 Ibid., p. 13

70 Verkuyten, 'Religious group identification and inter-religious relations', p. 344.

71 Ibid. 